\title{
In vitro and in vivo replication of turbot aquareovirus (TRV) in turbot tissues
}

\author{
Carmen Rivas ${ }^{1}$, Isabel Bandín ${ }^{1}$, Manuel Noya ${ }^{2}$, Catalina Cepeda ${ }^{1}$, Juan L. Barja ${ }^{1}$, \\ Carlos P. Dopazo ${ }^{1, *}$
}

${ }^{1}$ Departamento de Microbioloxía e Parasitoloxía, ${ }^{2}$ Departamento de Bioloxía Fundamental, Facultade de Bioloxía, Universidade de Santiago de Compostela, E-15706 Santiago de Compostela, Spain

\begin{abstract}
The replication of the turbot aquareovirus TRV in turbot tissues was studied in vitro in excised turbot tissues, and in vivo, following the evolution of viral titers in organs and tissues from experimentally infected turbot fry. Replication of TRV in vitro was demonstrated in kidney (with an increase of viral titer of more than 2 logs in $5 \mathrm{~d}$ ), but also in liver and heart (increasing more than $1 \log$ ). Viral replication was also demonstrated in vivo, with the kidney being the possible target organ. The virus was detected in most tissues of turbot fry $2 \mathrm{~h}$ post infection, which suggests involvement of the circulatory system in the rapid spreading of the virus to all fish organs and tissues. It appears that stress conditions, and/or simultaneous occurrence of bacterial infections, can enhance the replication of TRV in turbot, and the virus is more efficiently released to the environment. Our results suggest that, under normal conditions, TRV shows low levels of replication in turbot tissues, and thus infected fish may behave as asymptomatic carriers, spreading the virus to the environment and healthy fish.
\end{abstract}

KEY WORDS: Aquareovirus $\cdot$ Replication

\section{INTRODUCTION}

During the last decade, viruses with characteristics of the Reoviridae have been isolated from a number of aquatic animals. Recently these viral isolates have been grouped in the new genus Aquareovirus (Francki et al. 1991). Some of these viruses were isolated from diseased aquatic animals, although most of them were isolated during routine examination of asymptomatic fish.

The turbot aquareovirus (TRV) was isolated in northwest Spain from turbot suffering a mixed bacterial and viral infection (Lupiani et al. 1989), causing low but economically serious mortalities in a few turbot farms Since then, the virus has been repeatedly isolated from the same and other fish farms. These later isolations were consistently made in fish after physical stress and/or concomitant with bacterial infections.

Many reports have been published on the characterization, mechanisms of infectivity and replication of

\footnotetext{
-Addressee for correspondence.E-mail: mpdopazo@usc.es
}

several aquareovirus strains (see reviews by Winton 1989, Hetrick et al. 1992, Hetrick \& Hedrick 1993). However, to our knowledge there is no information about how the virus spreads throughout the fish tissues. In the present work, the replication of TRV in different fish tissues, in vitro and in vivo, as well as the route of entry of the virus into the host and subsequent spread throughout the fish tissues was studied. Additionally, the effect of stress conditions and mixed infection on viral replication was also investigated.

\section{MATERIALS AND METHODS}

Cell lines and viruses. Chinook salmon embryo (CHSE-214) cells (Lannan et al. 1984) were grown in Eagle's minimum essential medium (EMEM) supplemented with $5 \%$ foetal bovine serum (FBS), penicillin $\left(100 \mathrm{IU} \mathrm{ml^{-1 }}\right)$ and streptomycin $\left(100 \mu \mathrm{g} \mathrm{ml} \mathrm{m}^{-1}\right)$. The cells were incubated at $15^{\circ} \mathrm{C}$, and when confluent the growth medium was replaced by maintenance medium (EMEM with $2 \%$ FBS). 
The turbot aquareovirus (TRV), originally named turbot reovirus, was first isolated from a mixed bacterial-viral syndrome affecting turbot Scophthalmus maximus cultured in Spain (Lupiani et al. 1989). Prior to the experiments, the virus was re-isolated from experimentally infected turbot, and subjected to 3 serial passages in CHSE-214. The virus was propagated in $25 \mathrm{~cm}^{2}$ flasks of CHSE-214 monolayers at $15^{\circ} \mathrm{C}$. Viral titers were determined according to the method of Reed \& Müench (1938), using 96-well plates of confluent CHSE-214 cells, and are expressed as TCID $\mathrm{T}_{50} \mathrm{ml}^{-1}$.

Bacterial strain. A strain of Vibrio damsela (RG191) isolated from diseased turbot concomitant with TRV was used in the experimental bacterial and viral infections. The lethal dose $50 \%\left(\mathrm{LD}_{50}\right)$ of this strain for turbot is about $10^{3}$ cells (Fouz et al. 1992). For the challenge experiments, the bacteria were grown on trypticase soy agar supplemented with $1 \% \mathrm{NaCl}$. After $24 \mathrm{~h}$ incubation at $25^{\circ} \mathrm{C}$ the bacteria worc resuspended in sterile phosphate buffered saline (PBS), adjusted to $10^{7}$ cells $\mathrm{ml}^{-1}$ and serially diluted to the appropriate concentrations.

Fish. The tissues used in the in vitro study were obtained from yearling turbot averaging $700 \mathrm{~g}$. For the in vivo experiments, turbot fry weighting 3 to $5 \mathrm{~g}$ were employed. Rainbow trout Oncorhynchus mykiss fry ( 3 to $5 \mathrm{~g}$ ) were also used for comparative purposes. The fish were obtained from 2 hatcheries known to be free of viruses and maintained at 15 to $18^{\circ} \mathrm{C}$ in seawater tanks. Prior to use in the experiments, fish from these stocks were examined for bacterial or viral agents.

In vitro study of TRV replication. In vitro infection of fish tissues was accomplished basically as described by Yamamoto et al. (1992). Several organs and tissues (gill, fin, skin, spleen, brain, kidney, liver, stomach, intestine, gonad, muscle, heart and eye) were clipped from freshly killed yearling turbot. Tissue pieces were rinsed and placed in 12-well plates containing $5 \mathrm{ml}$ EMEM per well, and infected by addition of $100 \mu \mathrm{l}$ of the viral suspension $\left(3.1 \times 10^{4} \mathrm{TCID}_{50} \mathrm{ml}^{-1}\right)$ per well. Adsorption of the virus to the tissues was allowed for $1 \mathrm{~h}$ at $4{ }^{\circ} \mathrm{C}$ on a rocker platform (Selecta, Spain) and then unattached virus was removed by rinsing and draining the pieces 7 times. The tissues were placed in new plates containing EMEM, and incubated at $15^{\circ} \mathrm{C}$. Replicated tissue pieces were sampled daily during $5 \mathrm{~d}$, pooled and homogenized in their own culture medium, and processed for viral titration.

In vivo replication in fish tissues. In order to determine the replication capacity of TRV in turbot organs and tissues in vivo, as well as the route of entry and subsequent spreading of the virus, fish were infected in 2 different ways: (1) by intraperitoneal (IP) injection and (2) by immersion in a virus-containing bath. For all experiments, half of the water in the aquaria holding fish was renewed weekly.
IP injection of turbot fry: A total of 120 turbot fry ( 3 to $5 \mathrm{~g}$ ) were distributed in 3 stocks of 40 individuals each in tanks containing $20 \mathrm{l}$ of sea water Fish from aquarium $A$ were IP injected with $0.1 \mathrm{ml}$ of a viral suspension with an approximate titer of $1.7 \times$ $10^{5} \mathrm{TCID}_{50} \mathrm{ml}^{-1}$ (Expt A). In order to determine if stress conditions in the fish could affect the replication and spreading of the virus, fish from aquarium $B$ were subjected to the handling stress method described by Möck \& Peters (1990), and then inoculated as in Expt A (Expt B). To determine whether a bacterial infection in the fish could modify the virulence and spreading of TRV through the turbot tissues, fish from aquarium $\mathrm{C}$ were infected with Vibrio damsela by immersion for $5 \mathrm{~min}$ in a bath containing a sublethal bacterial concentration $\left(<10^{3}\right.$ cells $\mathrm{ml}^{-1}$ ) (Fóuz et al. 1992), and then IP injected with the virus as in Expt A (Expt C). Groups of fish injected with different bacieridi cioses, as weì as with PBS, were used as controls.

At $2,4,6,8,12$, and $24 \mathrm{~h}$, and then at $8,21,36$, and $48 \mathrm{~d}$ post infection (p.i.), 3 fish from each group were sampled and the following organs and tissues aseptically removed: brain, heart, kidney, spleen, liver, stomach, intestine, eye, muscle, skin, fin, gill, and blood. The remaining fish from each stock were not sampled in order to study the possible evolution of symptoms and/or mortalities. In addition, aliquots of water were collected at $0,7,14,21$, and $48 \mathrm{~d}$ from each tank, and assayed for viral titration.

Water challenge of turbot (Expt D): A group of 30 turbot fry were infected by direct immersion in a $20^{\circ} \mathrm{C}$ water bath containing approximately $3 \times 10^{4} \mathrm{TCID}_{50}$ $\mathrm{ml}^{-1}$. After $1 \mathrm{~h}$, fish were transferred back to the corresponding tank. Fish immersed in virus-free water were used as controls. Samples of 3 fish were collected at 2 , $4,6,8,12$, and $24 \mathrm{~h}$, and then at $8,21,36$, and $48 \mathrm{~d}$ p.i. and tissues aseptically removed. Aliquots of water were collected at $0,7,14,21$, and $48 \mathrm{~d}$, and assayed for viral titration.

Concentration of virus from water of tanks: When no virus was detected by the conventional method described above, the water from the tanks was concentrated using tangential flow filtration (TFF). This was accomplished using the Minitan-S Ultrafiltration System (Millipore) as described by Watanabe et al. (1988) with some modifications. A volume of 51 of autoclaved marine water was supplemented with $0.1 \%$ FBS and prefiltered through a $1.2 \mu \mathrm{m}$ cellulose filter (RA type, Millipore) to eliminate particulate matter. For the TFF, a 100000 Da molecular weight exclusion polysulfone filter (Millipore) was prepared by flushing with the prefiltered marine water. The water from the fish tanks was supplemented with $0.1 \%$ FBS, prefiltered as indicated above, and concentrated through 
the pretreated polysulfone membrane until the volume was reduced to $20 \mathrm{ml}$. Viral titration was performed as described previously.

Virological analysis of fish samples. All the organs and tissues (except blood) were weighed, diluted 1:5 (w/v) in EMEM containing double strength antibiotics. and separately homogenized in an OMNI-5000 homogenizer (OMNI International, Waterbury, CT, USA). The resulting suspensions were centrifuged for $10 \mathrm{~min}$ at $2000 \times g$ and the supernatants harvested and processed for viral titration, employing CHSE-214 cells as described before. Blood samples were collected from the caudal vein using heparinized syringes, diluted 1:5 in EMEM with double strength antibiotics, and subjected to freezing-thawing. After pelleting cell debris, the supernatant was harvested and processed for viral titration.

To determine viral titer per fish, the weight of each tissue (in grams) was multiplied by its corresponding viral titer (given as $\mathrm{TCID}_{50} \mathrm{~g}^{-1}$ of tissue), and the results for all organs and tissues were combined.

Serum titration. Sera samples taken at $1,8,21,36$, and $48 \mathrm{~d}$ p.i. were tested for the presence of neutralizing activity against TRV using a standard neutralization test. Briefly, 10 -fold serial dilutions of the sera were mixed with equal volumes of a viral suspension containing approximately $10^{3} \mathrm{TCID}_{50}$ of infectious virus, and incubated at room temperature for $1 \mathrm{~h}$ before inoculation in CHSE-214 monolayers. Results were read after $14 \mathrm{~d}$ incubation at $15^{\circ} \mathrm{C}$ and the titers calculated according to the method of Reed \& Müench (1938).

Experimental infection of turbot erythrocytes. Blood was collected with heparinized syringes from the caudal veins of juvenile turbot averaging $700 \mathrm{~g}$. Blood cells were washed 5 times with PBS, resuspended in EMEM and transferred to 24 - well plates to yield about $10^{7}$ erythrocytes per well. Infection of erythrocytes with TRV was performed by inoculation of $100 \mu \mathrm{l}$ of virus with a viral titer of $1 \times 10^{3} \mathrm{TCID}_{50} \mathrm{ml}^{-1}$. After 1 h of adsorption, cells were washed twice with PBS, resuspended in $0.5 \mathrm{ml}$ of EMEM, transferred to new plates and incubated at $15^{\circ} \mathrm{C}$. At $2,4,6,8,10,12,16,20$, and $24 \mathrm{~h}$, supernatant and cells from each well were removed and subjected to low speed centrifugation. The supernatant was processed for viral titration, and the pellet resuspended in $200 \mu \mathrm{l}$ of EMEM and subjected to freezing-thawing. After pelleting of cell debris, the supernatant was processed for viral titration as above.

\section{RESULTS}

\section{Replication of TRV in turbot tissues and erythrocytes}

The viral titers in liver and heart (Fig. 1) showed increases of 1.3 and $1.0 \log \mathrm{TClD}_{50} \mathrm{~g}^{-1}$, respectively. An increase in viral titer of more than 2 logs was observed only in kidney. No increase of viral titer was detected in gonad, intestine, eye, gill, stomach, spleen, muscle, and brain, and no virus was detected in fin after $5 \mathrm{~d}$ p.i. (data not shown). The titer of TRV in skin increased from $2.5 \log \mathrm{TCID}_{50} \mathrm{~g}^{-1}$ at time 0 to $2.9 \log \mathrm{TCID}_{50} \mathrm{~g}^{-1}$ at $5 \mathrm{~d}$ p.i. (data not shown), but this difference was not significant. Additionally, virus was not detected in TRV-infected erythrocyte cultures at any time tested.

\section{Replication of TRV in intraperitoneally infected turbot}

IP injection of TRV (Expt A.) resulted in the rapid spread of the viral agent through the fish. In fact, virus was detected in all fish organs and tissues as early as $2 \mathrm{~h}$ p.i. (Table 1). At this time, the kidney showed the highest concentration of virus, with a titer of $4.7 \mathrm{log}$ $\mathrm{TCID}_{\mathrm{so}} \mathrm{g}^{-1}$ of tissue, remaining relatively stable throughout the experiment. High titers were also found in blood, as well as in the stomach, spleen and liver. Gill, heart, eye, and brain contained the lowest concentrations of virus per gram of tissue.

Regarding the results obtained using stressed turbot (Expt B) (data not shown), viral titers were in general lower than those observed in Expt $A$, and detection of virus at $2 \mathrm{~h}$ p.i. was accomplished in some but not all fish tissues. The virus was detectable only for short periods of time in fin and brain. No virus was isolated from the eyes at any time.

With respect to the mixed infection assay (Expt C) (data not shown), the titer of virus isolated from each organ and tissue was, in general, slightly lower than those found in fish from Expt A. Virus was detectable at $2 \mathrm{~h}$ p.i. only in kidney, blood, spleen, and stomach. In gill and eye, virus was first detected at $6 \mathrm{~h}$ p.i., and at

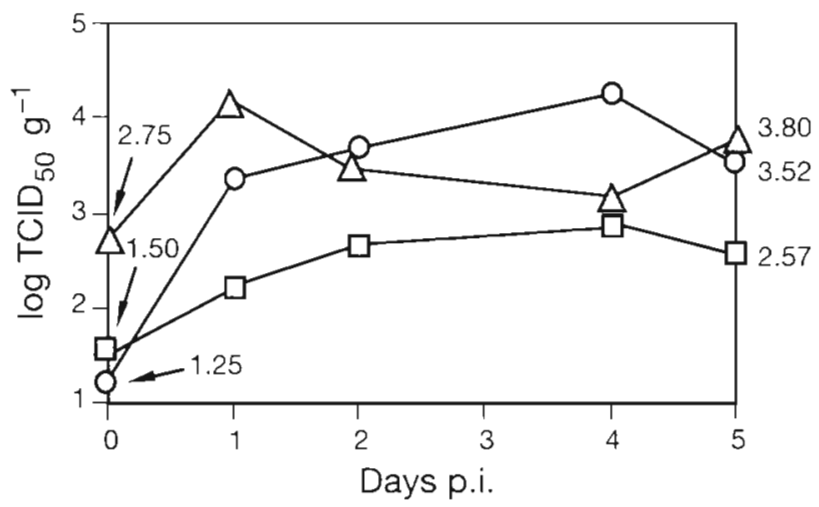

Fig.1. In vitro replication of turbot aquareovirus (TRV) in tissues excised from yearling turbot. (O) Kidney, $(\square)$ liver, $(\triangle)$ heart. Tissues were placed in 12 -well plates containing EMEM, inoculated with TRV and sampled after $1 \mathrm{~h}$ and then daily for virus. Titers are expressed as $\log \mathrm{TCID}_{50} \mathrm{~g}^{-1}$ tissue. Days p.i. are days post infection 
$12 \mathrm{~h} \mathrm{p.i.} \mathrm{in} \mathrm{fin.} \mathrm{In} \mathrm{the} \mathrm{remaining} \mathrm{tissues,} \mathrm{the} \mathrm{first} \mathrm{iso-}$ lation of virus was effected at $4 \mathrm{~h}$ p.i. Although virus was isolated for only a short period of time from fin, in the remaining tissues TRV was detectable until the end of the experiment ( $48 \mathrm{~d}$ ). As in Expt A, the kidney was the organ showing the highest viral titers.

No mortalities occurred and no clinical signs were observed in the infected fish during the course of any of the experiments. No anti-TRV neutralizing antibodies were detected in fish serum.

\section{Infection of turbot by immersion}

In this assay, viral titers per fish were clearly lower than in the IP experiments, with a maximum titer of $1.9 \times 10^{3} \mathrm{TCID}_{50}$ fish $^{-1}$ (data not shown). As shown in
Table 2, the titers of virus found in each tissue were clearly low. TRV was detectable throughout the experiment only in the intestine. Virus was detected in the blood from $4 \mathrm{~h}$ p.i. to the end of the experiment. These tissues showed, in general, the highest viral titers. No virus was detected in eye and brain tissues, and only at $2 \mathrm{~h} \mathrm{p.i.} \mathrm{in} \mathrm{the} \mathrm{spleen} \mathrm{and} \mathrm{stomach.} \mathrm{In} \mathrm{the} \mathrm{remaining}$ tissues virus was isolated for short periods of time. Infected fish did not show any symptoms, and no mortalities occurred. No anti-TRV antibodies were detected in fish serum by neutralization tests.

\section{Detection of TRV in the water of fish tanks}

Table 3 shows the titer of virus isolated from the water of fish tanks for each experiment. Detection of virus by the conventional method was only effected at the latest time points in the water of tanks corresponding to Expts B $\left(3.5 \times 10^{5}\right.$ TCID $_{50} 20 \mathrm{l}^{-1}, 48 \mathrm{~d}$ p.i.) and $\mathrm{C}(1.1 \times$ $10^{5}$ TCID $_{50} 20 \mathrm{l}^{-1}, 24 \mathrm{~d}$ p.i., and $1.1 \times$ $10^{6} \mathrm{TCID}_{50} 20 \mathrm{l}^{-1}, 48 \mathrm{~d}$ p.i. $)$. In the remaining experiments virus was detected only after TFF concentration of tank water, although viral titers observed were relatively low $\left(2.1 \times 10^{3} \mathrm{TCID}_{50} 20 \mathrm{l}^{-1}\right.$ for Expt $\mathrm{A}_{1}$ and $4.6 \times 10^{2} \mathrm{TCID}_{50} 20 \mathrm{l}^{-1}$ for Expt D).

\section{DISCUSSION}

Since the turbot aquareovirus has always been isolated in association with bacterial infections and/or stress conditions (authors' unpubl. data), we undertook this study of TRV replication in fish tissues and the effect of stress conditions on the viral replication.

To determine if TRV was able to replicate in turbot tissues, we carried out an in vitro assay using tissues obtained from healthy turbot, infecting them with the virus, and monitoring viral titers over a $5 \mathrm{~d}$ period. Our results suggest that TRV is able to replicate in the kidney, as an increase of more than 2 logs in viral titer was detected. It is tempting to consider that the virus can also replicate in liver and heart, although these tissues showed viral titer increases only slightly more than $1 \log$ The remaining tissues do not seem to be able to support replication of TRV. Other authors have also used excised fish tissues to study the replication of viruses such as viral hemorrhagic 
Table 3. Titration of TRV level in the water of tanks of infected turbot. nd: not detected, nt: not tested

\begin{tabular}{|c|c|c|c|}
\hline \multirow[t]{2}{*}{ Method of fish exposure to virus } & \multicolumn{3}{|c|}{ Method } \\
\hline & $\begin{array}{l}\text { Viral titer } \\
\left(\mathrm{TClD}_{50} 2 \mathrm{l}^{-1}\right)\end{array}$ & $\begin{array}{l}\text { Time }^{\text {d }} \\
\text { (d) }\end{array}$ & $\left(\mathrm{TCID}_{50} 20 \mathrm{l}^{-1}\right)$ \\
\hline IP injection of turbot (Expt A) & nd & nd & $2.1 \times 10^{3}$ \\
\hline IP injection of stressed turbot (Expt B) & 3) $3.5 \times 10^{5}$ & 48 & nt \\
\hline Mixed infection (Expt C) & $1.12 \times 10^{5}$ & 24 & $\mathrm{nt}$ \\
\hline & $1.12 \times 10^{6}$ & 48 & nt \\
\hline Water challenge (Expt D) & nd & nd & $4.6 \times 10^{2}$ \\
\hline
\end{tabular}

Other data from the in vivo experiments showed that higher viral titers were in general found in the kidneys of infected fish, which is a result similar to that obtained from the in vitro assay. This indicates that the kidney could be the target organ for TRV replication, as has been reported for other fish viruses (de Kinkelin et al. 1979, Ahne \& Wolf 1980, Chilmonczyk 1980, Amlacher 1986); however, further histological/immunohistochemical studies are needed to verify that assumption.

septicemia (VHSV) or infectious hematopoietic necrosis virus (IHNV) (de Kinkelin \& Castric 1982, Yamamoto et al. 1992), confirming the ability of those viruses to replicate in epidermal fish tissues.

Since the in vitro study can only be considered as an approximation of what really happens in infected fish, we performed an in vivo study using 2 routes of infection of turbot with TRV: IP injection and immersion Titers of total virus in IP-inoculated fish were very close to the quantity of virus injected at the starting point, which seems to indicate that TRV was not really replicating in the fish tissues but is stable within the fish. However, the detection of TRV in the water of tanks at the latest time points, despite repeated changes of water, suggests that the virus was replicating and being shed into the water, as has been reported for other viruses (Wolf et al. 1968, Billi \& Wolf 1969, Mortensen et al. 1990).

The detection of low levels of virus in the water from Expts A and D only after TFF concentration could be due to lower replication and/or less release of the virus with respect to Expts $B$ and $C$, which suggests that stress conditions affecting the fish, or simultaneous occurrence of a bacterial infection, could yield a rise in the level of viral replication. Taking into account that stressful conditions result in an increase in susceptibility of the fish to pathogenic organisms (Wedemeyer 1970, Snieszcko 1974, Walter \& Plumb 1980, Ellis 1981, Gratzek \& Reinert 1984, Peters et al. 1988), we think it would not be risky to say that those special conditions could lead to higher replication of the virus in the turbot. It seems that under normal conditions the fish are not greatly affected by the virus, although it can remain in the tissues at low levels, and such asymptomatic carriers can spread the virus to uninfected turbot. Special conditions, such as those cited above, could enhance TRV replication, and could have led to the viral isolations as well as the development of certain symptoms seen in the affected fish on the fish farms.
On the other hand, it is known that IP infection is not a natural route for studying pathogenesis and, therefore, more emphasis should be placed on water challenges. Viral titers obtained from the water-challenged fish were in general lower than from the IP experiments, and virus was not present in all tissues. Mortensen et al. (1990), studying scallops infected with infectious pancreatic necrosis virus (IPNV), obtained similar results and suggested that inactivation and/or release of the virus was more efficient when infection was performed through water challenge. Moreover, the fact that the earliest detection of TRV in the water challenge experiment was in the gill and gastrointestinal tract, but not in skin and fin, indicates that entry of the virus can be through the gills and/or oral region. The gills have been suggested to be the site of virus entry for the causative agents of spring viremia of carp (Ahne 1978) and viral hemorrhagic septicemia of trout (Chilmonczyk 1980, Neukirch 1984). Yamamoto \& Clermont (1990), studying the multiplication of IHN virus in trout organs following bath infection, observed that virus was first detected in gills and intestine and $2 \mathrm{~d}$ later in all the remaining tissues, suggesting that entry of the virus could be effected through the gills. On the other hand, entry of viral agents through the digestive tract is not usual. In this sense, Hassan \& Agius (1992) demonstrated that IPNV can be adversely affected, and even killed, during its passage through the digestive tract. However, more recently, Drolet et al. (1994) reported that IHNV enters rainbow trout through the oral region and moves into the gastrointestinal tract.

In the in vivo experiments described here, infection of turbot with TRV resulted in an early presence of the virus in most of the tissues, which indicates that the virus spreads quickly to all organs and tissues of the fish. Such a rapid dissemination of the virus has also been observed for other fish viruses (Yamamoto \& Clermont 1990). We think that the best way to explain such a rapid dissemination is through the circulatory 
system, and the isolation of relatively high viral titers from blood strongly supports this hypothesis. In this sense, Drolet et al. (1994) concluded that after entering the fish through the gills or oral region the IHN virus spreads into the circulatory system, which disseminates it to every organ. Since our results indicate that erythrocytes are unable to support either replication or intracellular presence of TRV, further studies must be conducted in order to determine if any other type of blood cells are implicated in the transport and dispersion of the virus throughout the fish.

Finally, our results showed that in many tissues the viral titer did not decline rapidly from that observed during the early stages of the infection, and the virus remained at detectable levels for extended periods of time. These findings suggest that exposure of turbot to TRV may produce a latent carrier state and the relatively low, but stable, viral titers found in all the tissues from the in vivo studies suggest that the IRV could be responsible for a self-limiting infection as has been reported for aquareoviruses (Winton et al. 1989). Asymptomatic chronically infected fish may periodically excrete the virus and, in doing so, contaminate the water and allow spread of the infection

Acknowledgements. This work was supported by Grants AGF 93-0796-C02-01 from the Comision Interministerial de Ciencia y Tecnología (CICYT), and XUGA 8030389 from Xunta de Galicia, Spain. C.R., and C.C. acknowledge the Ministerio de Educación y Ciencia, Spain, for research fellowships. The authors are grateful to Dr B. Fouz for her assistance in the infection experiments with the bacterium Vibrio damsela, and to Sergio Devesa from Neptuno Atlántico S.A. for kindly supplying the turbot. We thank the anonymous reviewers for useful comments which helped to improve this article.

\section{LITERATURE CITED}

Ahne W (1978) Uptake and multiplication of spring viraemia of carp virus in carp, Cyprinus carpio L. J Fish Dis 1. $265-268$

Ahne W, Wolf K (1980) Viruserkrankungen der Fische. In: Reichenbach-Klinke $\mathrm{H}$ (ed) Krankheiten und Schädigungen der Fische. Gustav-Fischer-Verlag, Stuttgart, p 63-66

Amlacher E (1986) Taschenbuch der Fischkranheiten, 5th edn. Gustav-Fischer-Verlag, Stuttgart

Billi BM, Wolf K (1969) Quantitative comparison of peritoneal washes and feces for detecting infectious pancreatic necrosis (IPN) virus in carrier brook trout. J Fish Res Bd Can 26:1459-1465

Chilmonczyk S (1980) Some aspects of trout gill structure in relation to Egtved virus infection and defense mechanisms. In: Ahne W (ed) Fish diseases. Springer-Verlag. Bertin, p 18-22

de Kinkelin P, Castric J (1982) An experimental study of the susceptibility of Atlantic salmon fry, Salmo salar L., to viral haemorrhagic septicaemia. J Fish Dis 5:57-65

de Kinkelin P, Chilmonczyk S, Dorson M, Le Berre M, Badouy AM (1979) Some pathogenic facets of rhabdoviral infec- tion of salmonid fish. In: Bachmann P (ed) Proc 4 th Munich Symp Microbiol: mechanisms of viral pathogenesis and virulence. WHO Collaborating Centre for Collection and Evaluation of Data on Comparative Virology, Munich, $p$ $357-375$

Drolet BS, Rohovec JS, Leong JC (1994) The route of entry and progression of infectious haematopoietic necrosis virus in Oncorkynchus mykiss (Walbaum): a sequential immunohistochemical study. J Fish Dis 17:337-347

Ellis AE (1981) Stress and the modulation of defence mechanisms in fish. In: Pickering AD (ed) Stress and fish. Academic Press, London, p 147-169

Fouz B, Larsen JL, Nielsen B, Barja JL, Toranzo AE (1992) Characterization of Vibrio damsela strains isolated from turbot Scophthalmus maximus in Spain. Dis Aquat Org 12:155-166

Francki RIB, Fauquet CM, Knudson DL, Brown F (eds) (1991) Classification and nomenclature of viruses. Arch Virol Suppl 2:1-450

Gratzek JB, Reinert R (1984) Physiological responses of experimental fish to stressful conditions. Natl Cancer Inst Monogr 65:187-193

Fassan MD, Agıus C (1992) A clinical study of experimentally induced infectious pancreatic necrosis virus (IPNV) infection in common carp. Cyprinus carpio Linnaeus. In: Shariff IM, Subasinghe RP, Arthur JR (eds) Diseases in aquaculture. Fish Health Sec, Asian Fish Soc. Manila, p 281-290

Hetrick FM, Hedrick RP (1993) New viruses described in finfish from 1988-1992. A Rev Fish Dis 3:187-207

Hetrick FM, Samal SK, Lupiani B, Dopazo CP, Subramanian $\mathrm{K}$, Mohanty SB (1992) Members of the family Reoviridae found in aquatic animals. Proc OJI Int Symp Salmonid Diseases. Hokkaido University Press, Sapporo, p 33-40

Lannan CN, Winton JR, Fryer JL (1984) Fish cell lines: establishment and characterization of nine cell lines from salmonids. In Vitro 20:671-676

Lupiani B, Dopazo CP, Ledo A, Fóuz B, Barja JL, Hetrick FM, Toranzo AE (1.989) New syndrome of mixed bacterial and viral etiology in cultured turbot Scophthalmus maximus. J Aquat Anim Health 1:197-204

Mök A, Peters G (1990) Lysozyme activity in rainbow trout, Oncorhynchus mykiss (Walbaum), stressed by handling, transport and water pollution. J Fish Biol 37:873-885

Mortensen SH, Hjeltnes B, Rødseth O, Krogsrud J, Christie KE (1990) Infectious pancreatic necrosis virus, serotype N1, isolated from Norwegian halibut (Hippoglossus hippoglossus), turbot (Scophthaimus maximus) and scallops (Pecten maximus). Bull Eur Ass Fish Pathol 10:42-43

Neukirch $M$ (1984) An experimental study of the entry and multiplication of viral haemorrhagic septicaemia virus in rainbow trout, Salmo gairdneri Richardson, after waterborne infection. J Fish Dis 7:231-234

Peters G, Faisal M, Lang T, Ahmed I (1988) Stress caused by social interaction and its effect on susceptibility to Aeromonas hydrophila infection in rainbow trout Salmo gairdner. Dis Aquat Org 4:83-89

Reed LJ, Müench H (1938) A simple method of estimating fifty percent endpoints. Am J Hyg 27:493-497

Snieszcko SF (1974) The effects of environmental stress on outbreaks of infectious diseases of fishes. J Fish Biol 6:197-208

Walter GR, Plumb JA (1980) Environmental stress and bacterial infection in channel catfish, Ictalurus punctatus Rafinesque. J Fish Biol 17:177-185

Watanabe RA, Fryer JL, Rohovec JS (1988) Molecular filtration for recovery of waterborne viruses of fish. Appl Env1ron Microbiol 54:1606-1609 
Wedemeyer $G$ (1970) The role of stress in the disease resistance of fishes. In: Snieszcko SF (ed) A symposium on diseases of fishes and shellfishes. Am Fish Soc, Spec Publ 5, Washington, DC, p 30-35

Winton JR (1989) Picornaviruses and reoviruses of fishes. In Ahne. W, Kurstak E (eds) Viruses of lower vertebrates. Springer Verlag, Berlin, p 217-226

Winton JR, Arakawa CK, Lannan CN, Fryer JL (1989) Isolation of a reovirus from coho salmon (Oncorhynchus kisutch) in Oregon, USA. In: Ahne W, Kurstak E (eds) Viruses of lower vertebrates. Springer-Verlag, Berlin. p $257-269$

Responsible Subject Editor: F. M. Hetrick, College Park, Maryland, USA
Wolf K, Quimby MC. Carlson CP, Bullock GL (1968) Infectious pancreatic necrosis: selection of virus-free stock from a population of carrier trout. J Fish Res Bd Can 25: 383-391

Yamamoto T, Batts WN, Winton JR (1992) In vitro infection of salmonid epidermal tissues by infectious hematopoietic necrosis virus and viral hemorrhagic septicemia virus. $J$ Aquat Anim Health 4:231-239

Yamamoto T, Clermont TJ (1990) Multiplication of infectious hematopoietic necrosis virus in rainbow trout following immersion infection: organ assay and electron microscopy. $\mathrm{J}$ Aquat Anim Health 2:261-270

Manuscript first received: March 12, 1995

Revised version accepted: November 23, 1995 